European launcher based on the British Blue Streak. The adoption of ELDO launchers for the scientific payloads as well as for the applications satellites will put launcher production on a rational basis (an average requirement of four a year). The report points out: "... the present situation is indeed unsatisfactory ... the programme as a whole is neither coherent nor balanced. It does not include any applications satellites ... and the launcher projects are mainly justified by applications satellite projects." It also calls for a sustained development programme for the ELDO vehicle, involving strap-on boosters, liquid hydrogen upper stages and possibly electric propulsion, for the tasks of the later seventies. The possible ELDO-4 launcher, for instance, would have about double the capacity of the present ELDO-1 specification and could place 2 tons in geostationary orbit, enabling direct-broadcast colour television to be supplied to all of Europe as well as Africa and the Middle East by 1978. Blue Streak is seen as perfectly suitable for the booster stage throughout the period.

A number of decisions are called for by the report, but, the authors point out, four of them are urgent and must be taken by the ministers this year-the future of the LAS, a start on the Eurovision satellite, increase in production of ELDO launchers and statutory bodies to handle the problems of organization. But what is needed most is a firm decision to pay. ESRO has been living from hand to mouth for two years now.

\section{CERN Meeting}

THE 37th meeting of the Council of CERN, held last week in Geneva, discussed the progress being made towards the building of the $300 \mathrm{GeV}$ accelerator. Most of the progress is at the organizational level, but it now seems clear that a final decision on the project should emerge by the end of this year, probably in December. There were also hopeful signs for supporters of the machine that fewer governments are dragging their heels than was the case at the end of last vear. The United Kingdom delegation, in particular, expressed itself completely satisfied with the answers given on design, cost, management and collaboration, and said that there was now no reason why these issues should be reopened. The German delegation was rather more subdued, for reasons of its own, but put forward no major objection.

It is now also clear that a decision about the siting of the laboratory should be made in the summer of this year, and a short list of four sites should be ready by June. At the moment, nine sites are still under consideration, and technical reports have now been published on each one. They are Aspropyrgos in Greece, Doberdo in Italy, Drensteinfurt in Germany, El Escorial in Spain, Focant in Belgium, Gopfritz in Austria, Le Luc in France, Mundford in the United Kingdom and Uppsala in Sweden. The final decision will be taken in two stages; a preliminary vote will be used to reduce the number of sites to four, and the delegates last week agreed that this vote should be taken in open ballot, though it is possible that it could be done in closed session. But, whatever the choice is to be, it will have to await promises of money which represent a substantial proportion of the cost of the accelerator. In other words, countries will have to commit themselves to the project before they know where it is to be built.
At the organizational level, the delegates agreed to the formation of a steering committee to work on the $300 \mathrm{GeV}$ project until an advisory committee for the project is formed. The function of the advisory committee would be to assist the director-general of the new laboratory, and it might also exercise some form of control. As a stopgap arrangement, the steering committee has been set up to fulfil this function; the membership is Professors Amaldi and Amman of Italy, Dr J. B. Adams and Professor Merrison of the UK, Dr Levy-Mandel of France, Professor Paul of Germany, and Drs Hine and Zilverschoon of CERN; the director-general of CERN is an ex-officio member. Several delegates emphasized the need for speed, particularly once the decision to go ahead has been taken. Professor Puppi of the Science Policy Committee, for instance, said that the name of a proposed director-general could be put forward very quickly. The feeling seems to be that the second the decision is taken, the delegates should dash from the meeting to lay the foundation stone, before anybody can change their minds.

\section{Engineers of the World Unite}

National engineering organizations from all over the world got together recently under the auspices of Unesco to form a World Federation of Engineering Institutions. At a meeting in Paris from March 4 to 7 , representatives from 60 countries and four regional organizations gave sanction to a plan to set up the federation. The hope is that it will do for engineering what the International Council of Scientific Unions does for science - a process of organization, co-operation and, to a limited extent, unification.

The World Federation will replace or supplement a number of other international bodies which for reasons of representation or organization were unable to do the job. There have been limited groupings of national institutions for a number of years - there was one in Europe, one for the Commonwealth, and another covering the Americas. These organizations will no doubt co-exist with the new one quite happily. The only organization whose continued existence is threatened is the Union des Associations Techniques Internationales, based in Paris, which has for some time been regarded as something of a lame duck. Uneseo has been pressing for a new organization for some years, and it seems that its gentle prompting met with a ready response from the national engineering institutions. At the Paris conference the federation was set up by a unanimous vote.

The first president of the federation will be the Swiss engineer Dr Eric Choisy, and Mr R. Gibrat of France will be vice-president. It seems likely that much of the executive work of the federation will be done at the Institution of Electrical Engineers in London-the secretary of the institution, Dr G. F. Gainsborough, has been appointed first secretarygeneral of the federation. The federation itself will consist of national members, which will be the representative engineering body for each country (in Britain the Council of Engineering Institutions), and some international members, representing existing federations throughout the world.

Dr Gainsborough is enthusiastic about his new responsibilities. Already, he says, two projects have been started. The first is to set up a committee to 
examine the qualifications and continuing development of engineers throughout the world. The ultimate aim, still a long way off, is international recognition of qualifications, so that an engineer from Poland, say, can have his qualifications recognized in Ethiopia. This committee will also help to speed the exchange of ideas in the education of engineers, and should help developing countries which are setting up departments of engineering. The other project started by the federation is to examine the possibilities of a world-wide information system, for dissemination and retrieval. This committee will be collaborating with the abstract board of ICSU. The federation has also started on a more abstract project, that of drawing up an international code of conduct for professional engineers.

The general work of the federation will be financed from contributions from member countries. The special committees, on the other hand, are each charged with responsibility for finding sources of funds for their investigations. Dr Gainsborough is hoping that Unesco, OECD and other international organizations will see the federation as a body worthy of support. There seems every likelihood that this hope will be justified.

\section{No Student Power at Oxford}

\section{from our Oxford Correspondent}

IT was too much to expect the Hebdomadal Council to comment other than adversely on the petition submitted to the Privy Council for various reforms in government of the University of Oxford. One of the three chief proposals of the petition, intended to give undergraduates direct representation in university affairs, would indeed have been without precedent in many less staid institutions. In its letter to the Privy Council, the Hebdomadal Council took an optimistic view of relations within the colleges between undergraduates and senior members, and justified its rejection of the proposal because the Student Representation Council is not highly regarded by the undergraduates themselves. The argument is circular; the SRC is not even recognized by, let alone allowed to participate in, the university government. Its lack of prestige among students is a reflexion of this. But in any case, the council's dismissal of the proposition will doubtless be justified shortly by the anarchic demise of the London School of Economics whose Board of Governors has decided to admit students to certain committees (see Nature, 21\%, 699; 1968).

A second proposal in the petition is that the convocation of the university's MÂs should be made into an active forum, rather than consigned to impotence as it will be under the Franks Commission's recommendations. This proposal indeed seems "unnecessary and undesirable". As the Hebdomadal Council points out, many members of convocation live abroad, and most are too busy to attend sessions.

The rejection of the third proposal of the petition, outlined at some length in Nature $(21 \%, 500 ; 1968)$, is not so easily defended. The Hebdomadal Council does not deny that, in the disciplinary procedure of the university, the proctors act both as judges and policemen, so that there is a possibility of bias in the judgment of students' misdeeds. Yet the council (which, it is worth noting, includes proctors) announces its satisfaction with the present arrangements. The council's claim that students are made aware of their right to appeal against proctorial decisions to an independent committee is indeed true. But this has no bearing on what is requested by the petition. If the proctors confined themselves to the carrying out of petty university regulations, such as the licensing of student's cars, then the reform of proctorial procedure would scarcely be worth the attention of the Privy Council, but the Oxford proctors, unlike their Cambridge counterparts, show little reluctance to act in cases where junior members have broken the law of the land, rather than simply that of the university. The proctors' terms of reference are wide and their punishments sometimes severe, and it is only reasonable that the slightest possibility of bias should be eliminated.

Among the signatories of the petition, senior members of the university outnumber juniors by 101 to 29 . In its letter to the Privy Council the Hebdomadal Council doubts whether the request of 100 out of the 1,600 members of the congregation (the "parliament of senior members") is enough to justify discussion of major constitutional changes. Yet it is well known that few senior members attend the congregation. Important issues have been decided with less than 200 people present. Outside observers might be expected to be surprised that so great a demand still exists for new reforms 18 months after the Commission of Inquiry issued its report. It will be interesting to see how this consideration weighs with the Privy Council as it studies the petition and the reply.

\section{More Teachers}

THE latest volume of Statistics of Education, 1966 (published by HMSO, price $£ 1$ ) starts on a cheerful note, for between October 1965 and October 1966, the number of students training to be teachers in England and Wales rose by more than 12,000, bringing the total to 88,823 . This represents an increase of nearly 75 per cent over the figure of 50,942 for 1962 . In addition there were 1,308 men and 654 women in one-year supplementary or advanced courses, and courses of one year for the teaching of handicapped children also showed a marked increase for the same period. Less reassuring is the decline in the proportion of students successfully completing training in both junior and secondary courses, even though the numbers and proportions in infant/junior and junior/secondary courses increased. Another unsatisfactory trend was the fall between 1963 and 1966 in the numbers of courses for secondary school teachers and students for them.

The increase in the total teaching force from 321,000 in 1962 to 349,000 for 1966 was most striking in the colleges of education, where the number of teachers was more than doubled. A 70 per cent increase for further education establishments is also a striking feature. Up to March 31, 1966, 20 per cent of teachers in maintained primary and secondary schools were graduates-the proportions ranging from 75 per cent of teachers in grammar schools to some 4 per cent in primary schools. About 33 per cent of teachers in establishments of further education were graduates, and graduates also accounted for more than 60 per cent of teachers in direct grant grammar schools.

But the figures showing the wastage of qualified teachers are dismally high. Thus between 1965 and $1966,9,000$ qualified men teachers entered maintained 